\title{
Investigate the NPK Agriculture Fertilizer as a Corrosion Inhibitor for Mild Steel in an Iraqi Crude Oil Refinery Tank
}

\author{
Adnan A. Ateeq \\ Corrosion Engineering Laboratory, Department of Petrochemical Engineering, \\ Basra Engineering Technical College, Southern Technical University \\ Basra / Iraq
}

\begin{abstract}
Storage tanks made from mild steel are always subject to corrosion when the conditions are permitting. Industrial water storage tanks located in Al-Shaiba, Basra, Iraq are suffering from severe corrosion, and research on the mitigation of this problem is underway. In this study, Nitrogen, Phosphorus and Potassium (NPK) fertilizer was added to the water stored in such tanks to study its effect as corrosion inhibitor. The material of the selected tank's wall is mild steel $(0.18 \% \mathrm{C})$. NPK fertilizer was prepared as electrolyte solution at different concentrations $(0.1,0.2,1$ and $2 \mathrm{~g} / \mathrm{l})$, and the study was conducted at $25{ }^{\circ} \mathrm{C}$. The corrosion rate and the penetration rate of the mild steel are measured by electrochemical measurements.
\end{abstract}

The study showed that mild steel possesses a good resistance to corrosion at $0.2 \mathrm{~g} / \mathrm{l}$ of the NPK inhibitor, in comparison to other concentrations of NPK. Above this concentration, the resistance to corrosion was found to be decreasing. This inhibitor could be recommended as good, cheap, and non-toxic material used to decrease the risk of corrosion in industrial processes.

Keywords: Corrosion, Mild steel, Agriculture fertilizer, NPK.

\section{INTRODUCTION}

One of the common building materials used in chemical processes is mild (carbon) steel. In order to achieve desired mechanical properties for iron, carbon is added at low percentage to the steel alloy, usually at $1 \%$ or less composition. ${ }^{1}$ The mechanical properties of carbon steel depend on the mentioned percentage of carbon in the alloy. For this reason, carbon steel is classified into three categories: Low, Medium and High Carbon Steels. Nonetheless, some references added a fourth classification as Very High Carbon Steel, which exceeds $1 \%$ carbon to $1.5 \% .{ }^{2}$ The addition of carbon to iron in one alloy results in favorable characteristics, such as easy processing (machinery and welding), and high ductility.

Carbon Steel is widely used in the construction of storage tanks used in crude oil processing facilities such as oil refineries, in marine applications, transportation, mining and metal-processing equipment. ${ }^{3}$

A major issue that is faced in many industrial processes is the corrosion of such tanks made from carbon steel. ${ }^{4}$ The reported losses due to corrosion-related issues were 276 billion US dollars annually in the United States alone, and reducing the pace of corrosion or inhibiting it became such an important subject for research. ${ }^{5}$

The Corrosion process is a chemical reaction that takes different stages. It starts at anodic areas whereby ferrous ions start to transfer into the aqueous phase in contact with the iron. The chemical reaction is given by the following formula: ${ }^{6}$

$$
4 \mathrm{Fe}+3 \mathrm{O}_{2}+2 \mathrm{H}_{2} \mathrm{O} \rightarrow 2 \mathrm{Fe}_{2} \mathrm{O}_{3} \cdot \mathrm{H}_{2} \mathrm{O}
$$

Which is literally translated into verbal formula as below:

$$
\text { Iron/Steel }+ \text { Oxygen }+ \text { Water } \rightarrow \text { Rust }
$$

Protecting carbon steel from corrosion has become an important field of research, attracting a great deal of interest from both academic and industrial sectors. Different methodologies and techniques were proposed to control and inhibit the corrosion of carbon steel. ${ }^{6}$ The most useful method was to 
add a chemical compound to the solution being stored in the tanks or passing through the pipelines that are intended to be protected. ${ }^{7}$ Such additives can be organic or inorganic inhibitors, as what was reported in different articles in the literature. ${ }^{8,9,10-15}$ Multiple studies have reported that inhibitors containing particular atoms, such as Nitrogen, Sulphur, and Oxygen act as good corrosion inhibitors. This is due to the ability of these atoms to adsorb on the surface of the steel and thereby forming a coordinate bond between the unpaired electrons present on such atoms and vacant d-orbitals located in mild steel. ${ }^{10,11,16,17}$ The corrosion rate for mild steel was found to be decreasing as a result to the adsorption of such inhibitors on the metal's surface, which leads to blocking the active site in the mild steel. A work by Bishof et al, ${ }^{18}$ which was patented in the United States, showed that orthophosphate, a compound that contains phosphor and oxygen only, is a reliable corrosion inhibitor to reduce the corrosion of iron. Şahin et al suggested the application of Nitrogen compounds as corrosion inhibitors for steel. It was shown that inhibition efficiencies were increasing while the concentration of Nitrogen compounds was increased in the solution. ${ }^{19}$ Another research by Larabi et al reported the use of Potassium Iodide as co-corrosion inhibitor for mild steel with the presence of Poly (4-vinylpyridine). ${ }^{20}$ They reported that the addition of Potassium Iodide considerably enhanced the corrosion inhibition ability of Poly (4-vinylpyridine). These facts led to the hypothesis that a compound containing Nitrogen, Phosphorous, and Potassium atoms may serve as a good corrosion inhibitor for mild steel.

Although the corrosion that affect carbon steel building materials is categorized into three different types, i.e. Atmospheric corrosion, Aqueous corrosion and Soil corrosion, the current study deals with Aqueous corrosion of carbon steel. In this study, NPK fertilizer as defined earlier, with $20 \%$ Nitrogen; $20 \%$ Phosphorous; and $20 \%$ Potassium composition was tested for the hypothesis that was built during the pre lab work step. The study was aimed to generate results from applying NPK fertilizer as corrosion inhibitor for mild steel, and to analyze the results and come up with a conclusion that either supports or denies the hypothesis. Al-Shaiba Oil Refinery (AOR) in Basrah, Iraq contains a section of makeup water where it is a main supply for various units. This water is treated with Alum and Chlorine before being sent to other units, such as the reverse osmosis (RO) unit, the cooling towers, and the fire extinguishing pumps. A tank located in the makeup water unit (Tank number 2204) is built of mild steel walls and floor. It is suffering from severe corrosion, and thus, it was chosen to be the subject of this study.

Such corrosion is faced in different tanks in the same refinery, a problem that negatively affected the production rate of the mentioned refinery and created environmental issues. The experiments were conducted at $25{ }^{\circ} \mathrm{C}$ in order to mimic the environmental conditions of that tank according to the AOR.

\section{Materials AND Methods}

\subsection{Materials}

The carbon steel that was subject to this study is an alloy of different elements. Table 1 shows the chemical composition of carbon steel $(0.18 \% \mathrm{C}) 1 \mathrm{~cm}^{2}$ alloy used in this study. The composition was obtained after analyses by X-Ray Photoelectron Spectroscopy (XPS) (Instrument supplied by Thermo Fisher Scientific (ESCALAB)).

Table1. Chemical composition of carbon steel alloy

\begin{tabular}{|c|c|}
\hline Element & Wt\% \\
\hline $\mathrm{C}$ & 0.18 \\
\hline $\mathrm{Si}$ & 0.13 \\
\hline $\mathrm{Mn}$ & 0.44 \\
\hline $\mathrm{P}$ & 0.013 \\
\hline $\mathrm{S}$ & 0.019 \\
\hline $\mathrm{Cr}$ & 0.12 \\
\hline $\mathrm{Cu}$ & 0.24 \\
\hline $\mathrm{Fe}$ & Balance \\
\hline
\end{tabular}

A cut of the tank's roof (similar alloy to walls and floor) with area of $900 \mathrm{~cm}^{2}$ was made and brought to the laboratory to subject it to the different tests of this study. NPK fertilizer was acquired from SDT Industries, Inc. (Winnsboro, LA., USA). The fertilizer is of 99\% purity and was used as received from the manufacturer. Table 2 shows the composition of the fertilizer as supplied by the manufacturer. 
Investigate the NPK Agriculture Fertilizer as a Corrosion Inhibitor for Mild Steel in an Iraqi Crude Oil Refinery Tank

Table2. Chemical composition of NPK fertilizer

\begin{tabular}{|c|c|}
\hline Compound & Wt\% \\
\hline Total Nitrogen & 20 \\
\hline Total Phosphoric Acid & 20 \\
\hline Water soluble Potash & 20 \\
\hline Boron & 0.02 \\
\hline Cu & 0.05 \\
\hline Manganese & 0.05 \\
\hline Zinc & 0.05 \\
\hline Molybdenum & 0.01 \\
\hline Others & Balance \\
\hline
\end{tabular}

Water was taken from the same tank (number 2204) to prepare the NPK (fertilizer) electrolyte solution. The water has been analyzed and found to possess the characteristics listed in Table 3.

Table3. Characteristics of the water taken from Tank number 2204

\begin{tabular}{|c|c|}
\hline $\mathrm{pH}$ & 7.9 \\
\hline Conductivity $\left(\mathrm{ms} . \mathrm{cm}^{-1}\right)$ & 4.49 \\
\hline $\mathrm{CaCO}_{3}(\mathrm{mg} / \mathrm{l})$ & 1058 \\
\hline $\mathrm{Ca}^{+2}(\mathrm{mg} / \mathrm{l})$ & 232 \\
\hline $\mathrm{Mg}^{+\quad}(\mathrm{mg} / \mathrm{l})$ & 116 \\
\hline $\mathrm{CL}^{-}(\mathrm{mg} / \mathrm{l})$ & 998 \\
\hline $\mathrm{Na}^{+}(\mathrm{mg} / \mathrm{l})$ & 638 \\
\hline $\mathrm{HCO}_{3}(\mathrm{mg} / \mathrm{l})$ & 214 \\
\hline $\mathrm{Suspended} \mathrm{solids}(\mathrm{mg} / \mathrm{l})_{|c|}$ & 6 \\
\hline $\mathrm{SiO}_{3}(\mathrm{mg} / \mathrm{l})$ & 6 \\
\hline $\mathrm{C} . \mathrm{O}^{*}(\mathrm{mg} / \mathrm{l})$ & 21 \\
\hline B.O.D** $(\mathrm{mg} / \mathrm{l})$ & 9.7 \\
\hline
\end{tabular}

*Chemical Oxygen Demand

** Biochemical Oxygen Demand

\subsection{Inhibitor Electrolyte Solution}

NPK stock solution was prepared by dissolving two grams of NPK in one liter of the water described in the materials section earlier. This produced a stock solution of $2 \mathrm{~g} / \mathrm{l}$. The consequent concentrations $(0.1,0.5$, and $1 \mathrm{~g} / 1)$ were prepared by serial dilution of the stock solution.

\subsection{Sample Preparation}

The sample of mild steel cut was polished using sand paper starting from 100 to 180,220 , and finally 400 grits. It was then rinsed by water in order to avoid a possible change in the microstructure of mild steel. Following this step, the sample was rinsed with isopropanol to eliminate contamination to the sample.

\subsection{Electrochemical Measurements}

There are various polarization methods used for laboratory corrosion testing, such as potentiodynamic polarization, potentiostaircase, and cyclic voltammetry. They provide useful information about the corrosion mechanism, corrosion rate and susceptibility of specific materials to corrosion in designated environments. ${ }^{21}$ Potentiodynamic polarization method is used here.

A potentiostat (MLAP, Bank Electronik, Germany) and a three-electrode cell assembly were used for the electrochemical measurements. The cell consists of the mild steel cut as a working electrode (WE), a platinum rod as a counter electrode (CE) and a saturated calomel electrode (SCE) as a reference electrode (RE) in electrolyte solution. Fritted glass is used to separate the counter electrode from the working electrode. In order to minimize dynamic voltage (IR)drop, the reference electrode is connected to a Luggin capillary. The temperature of the cell was maintained at $25^{\circ} \mathrm{C}$. The mild steel sample was immersed in the solution for 3 hours before the electrochemical measurements were carried out. 


\section{RESULTS AND DISCUSSION}

The Figure 1 presents the potentiodynamic polarization behavior of mild steel in 5 different solutions. Starting from blank water (water brought from the tank number 2204 used as is, without adding NPK), then by increasing the concentration of NPK from $0.1 \mathrm{~g} / \mathrm{l}$ to $2.0 \mathrm{~g} / \mathrm{l}$ as was described earlier for the different concentrations prepared for NPK in water. This was to study the effect of the presence of NPK in the water as corrosion inhibitor to protect mild steel from corrosion. Each measurement was conducted after a period of three hours of immersion in the solution.

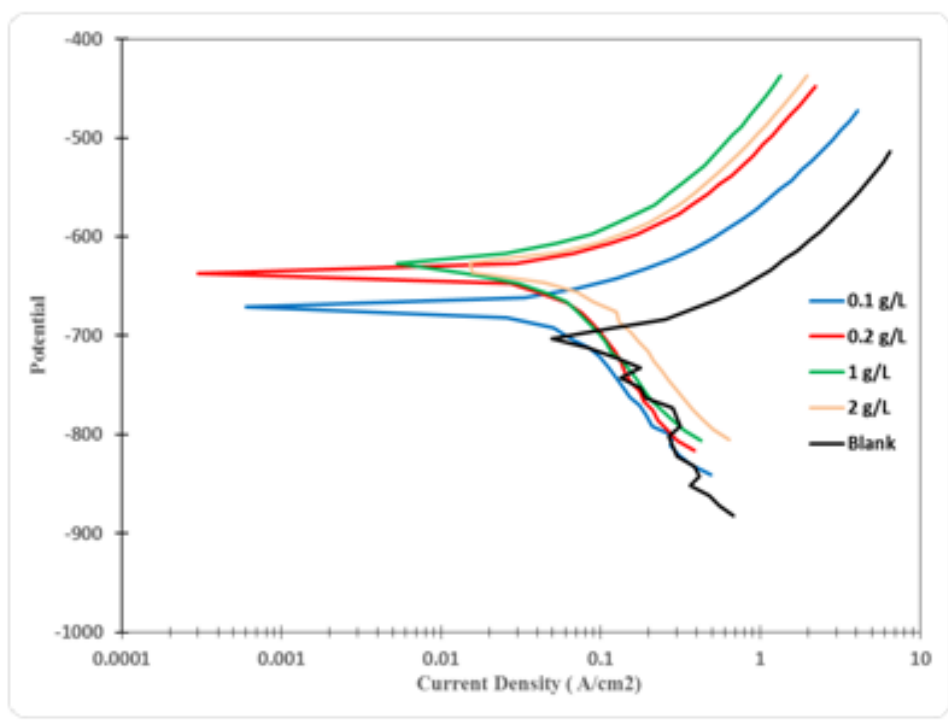

Fig1. Potentiodynamic curves for mild steel in water of the tank number 2204 in the presence and absence of various concentrations of inhibitors.

The figure shows that when the measurement was carried out in a blank water solution (no NPK added), the corrosion potential was measured to be $726.2 \mathrm{mV}$. The figure also shows how the corrosion potential changed as the concentration of the NPK was increased. It is clear that NPK's presence in the solution acts to shift the corrosion potential towards the anodic side, which means that NPK controls the anodic reaction predominantly by blocking the anodic sites of the metal surface. A similar behavior was reported in the literature. ${ }^{22-23}$ At a concentration of $0.2 \mathrm{~g} / \mathrm{l} \mathrm{NPK}$, the corrosion potential was at a value of $653.1 \mathrm{mV}$. This concentration seems to be the one that gives the most shift toward the anodic side, and thus, the optimum concentration of NPK solution to minimize the corrosion.

Various corrosion parameters, such as, corrosion potential (ECORR); corrosion current density (ICORR); corrosion rate (CR); percent inhibition efficiency (IE\%)and surface coverage degree $(\Theta)$ are given in Table 4. The potentiostat measures ECORR and ICORR and CR. The table also shows the percentage of decrease in corrosion rate (CR) when NPK is added to the water, known as inhibition efficiency (IE\%)is calculated from the following equation:

$$
\mathrm{IE} \%=100 \times \frac{C R_{\text {uni hibited }}-C R_{\text {in hibited }}}{C R_{\text {unin hibited }}}
$$

Where, $\mathrm{CR}_{\text {uninhibited }}$ is the corrosion rate of the uninhibited system and $\mathrm{CR}_{\text {inhibited }}$ is the corrosion rate of the inhibited system.

Table4. Polarization data for water of tank number 2204 in absence and presence of different concentrations of NPK fertilizer.

\begin{tabular}{|c|c|c|c|c|c|}
\hline $\begin{array}{c}\text { Conc. } \\
(\mathrm{g} / \mathrm{l})\end{array}$ & $\begin{array}{c}\mathrm{E}_{\mathrm{CORR}} \\
(\mathrm{mV})\end{array}$ & $\begin{array}{c}\mathrm{I}_{\mathrm{CORR}} \\
\left(\mu \mathrm{A} / \mathrm{cm}^{2}\right)\end{array}$ & $\begin{array}{c}\mathrm{CR} \\
(\mathrm{mm} / \mathrm{y})\end{array}$ & $\mathrm{IE}(\%)$ & $\theta$ \\
\hline 0.0 & -726.2 & 123.1 & 1.43 & 0 & 0 \\
\hline 0.1 & -678.2 & 52.1 & 0.60 & 57.6 & 0.57 \\
\hline 0.2 & -653.1 & 33.2 & 0.39 & 73.03 & 0.73 \\
\hline 1 & -629.1 & 37 & 0.43 & 69.94 & 0.69 \\
\hline 2 & -634 & 59.5 & 0.69 & 51.66 & 0.51 \\
\hline
\end{tabular}


When blank solution was used, the $\mathrm{I}_{\mathrm{CORR}}$ was at a high value of $123.1 \mu \mathrm{A} / \mathrm{cm}^{2}$, and the $\mathrm{CR}$ was at a high value of $1.43 \mathrm{~mm} / \mathrm{y}$. Similarly for blank solution, IE\% was calculated to be $0 \%$, i.e. no efficiency, and $\Theta$ was 0 , i.e. no coverage. Then the NPK solutions were studied, and we found that both of $\mathrm{I}_{\mathrm{CORR}}$ and $\mathrm{CR}$ are significantly decreased while IE\% and $\Theta$ are significantly increased in comparison to blank solution. These findings clearly show the advantages of incorporating the NPK in the solution. The decrease in CR was at a maximum of $73.03 \%$ when the solution was at NPK concentration of $0.2 \mathrm{~g} / \mathrm{l}$, which is a huge decrease and deserves consideration.

If we plot the $\mathrm{I}_{\mathrm{CORR}}$ and $\mathrm{CR}$ on the left and right $\mathrm{Y}$ axes, respectively, in one figure to show their trend, we would get Figure 2 below. This figure shows how varying the concentration of NPK in the solution impacted these two important factors, and where does the optimum concentration lie. Noticing that the need to plot two different $\mathrm{Y}$ axes is because of the huge difference in the scale required to put the two factors in one figure. From Figure 2, we noticed that at NPK concentration of $0.2 \mathrm{~g} / \mathrm{l}$, a minimum was achieved for both $\mathrm{I}_{\mathrm{CORR}}$ and CR.

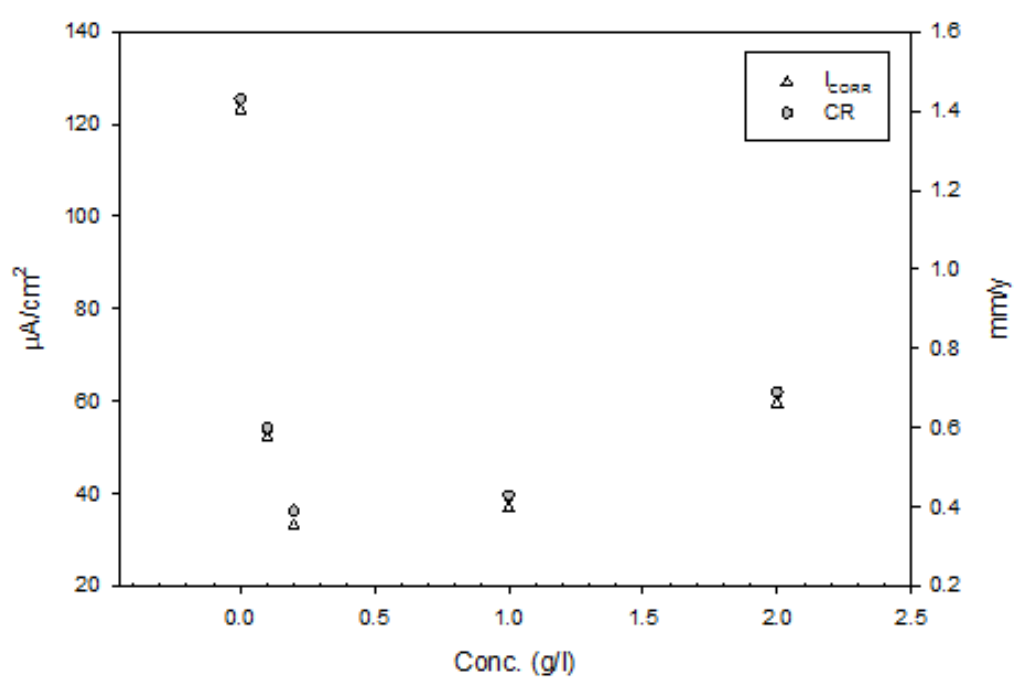

Fig2. Graphical representation of $I_{C O R R}$ and $C R$ as a function of NPK concentration in the solution

In a similar way, we plotted IE (\%) and $\Theta$ on the left and right $Y$ axes, respectively, in one figure. This is shown in Figure 3 below. The plot shows the finding of Figure 2, that at $0.2 \mathrm{~g} / \mathrm{l}$ of NPK solution, the maximum inhibition efficiency (IE \%) and surface coverage degree were achieved.

The possible mechanism of inhibition that is taking place here when NPK is added. NPK particles are being adsorbed on the surface of mild steel when there is a reduction reaction. The inhibitor-adsorbed area becomes resistant to corrosion, while the inhibitor-free area of the metal surface is subject to corrosion. This mechanism was reported in the literature. ${ }^{24}$

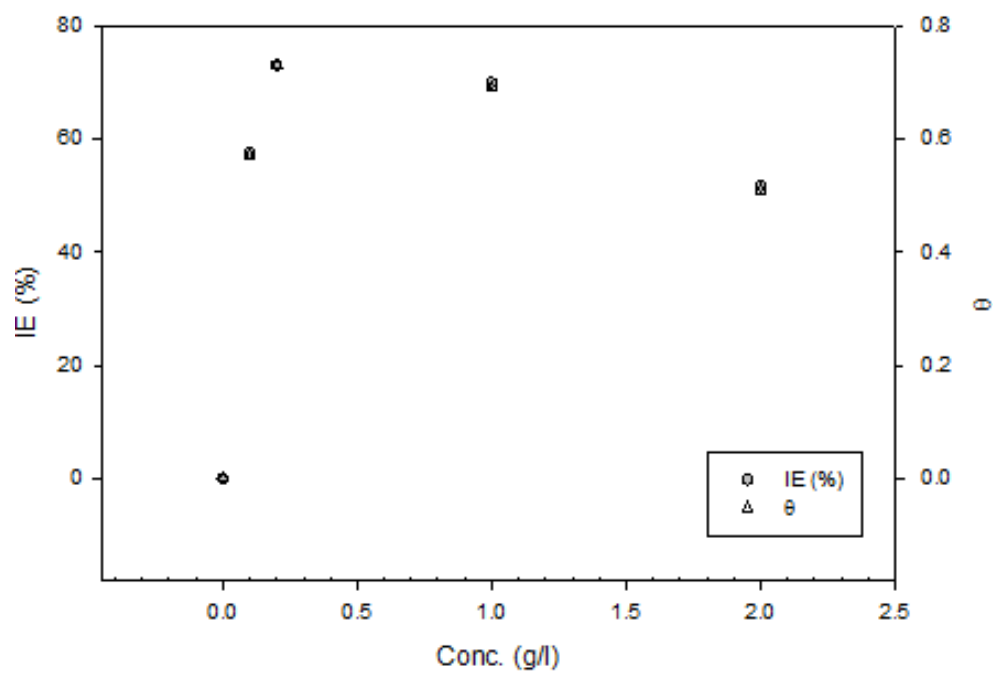

Fig3. Graphical representation of IE and $\Theta$ as a function of NPK concentration in the solution 


\section{Conclusions}

In this study, we wanted to tackle a very important issue that faces the oil industry in our region, south of Iraq. This issue is the corrosion of water storage tanks. Out of many techniques proposed for corrosion inhibition, we decided to study a simple, low-cost, and environment-friendly technique, which is the addition of NPK fertilizer as corrosion inhibitor. The experiments were conducted to investigate a possible decrease in the corrosion rate if NPK is added. Using electrochemistry measurement, we found that the addition of NPK at low concentrations (less than $1 \mathrm{~g} / \mathrm{l}$ ) to the water being stored in the tanks helped in decreasing the corrosion rate from $1.43 \mathrm{~mm} / \mathrm{y}$ to a minimum of $0.39 \mathrm{~mm} / \mathrm{y}$, which is a decrease of $73.03 \%$ from the original corrosion rate. The addition of NPK was found to be shifting the potential of mild steel electrode to more positive values indicating that NPK works as anodic inhibitor.

The corrosion mechanism is believed to be the adsorption of the NPK as inhibitor on the surface of the metal to protect it from reacting with the water and dissolved oxygen. NPK is a fertilizer used in the agriculture industry and thus it is non-toxic, and biodegradable.

\section{REFERENCES}

[1] Amstead, B, H, Ostwald P, F, Begeman M, L, (ed) 1987, “ Manufacturing Process, ” John Wiley Publication Singapore.

[2] Classification of Carbon and Low-Alloy Steels. Online material at: http://www.totalmateria. com/articles/Art62.htm. Date accessed May 22, 2016.

[3] Features and applications of common carbon steel alloys. Online material at: http://www. coburnmyers.com/materials-carbon-steel/. Date Accessed: May 22, 2016.

[4] Scott, C., Gui, F., Brossia, C. S., Beavers, J., Edgemon, G., Berman, H., Boomer, K., Frankel, G. A Study of Corrosion and Stress Corrosion Cracking of Carbon Steel Nuclear Waste Storage Tanks. Presented at Materials Science \& Technology 2007 Conference and Exhibition.

[5] Koch, G. H., Brongers, M. P. H., Thompson, N. G., Virmani, Y. P., Payer, J. H. US Department of Transportation, Publication No. FHWA-RD-01-156. Corrosion Costs and Preventive Startegies in the United States.

[6] Hudson, R. The Prevention of Corrosion on Structural Steelwork. CC\&I:JP:B2000:UK:05/2004. [corrosion rate and method] Aminu D. Usman, Linus N. Okoro. Mild steel corrosion in different oil types. International Journal of Scientific Research and Innovative Technology, 2, 2, 2015 (online).

[7] Oguzie, Emeka E. Evaluation of the inhibitive effect of some plant extracts on the acid corrosion of mild steel. Corrosion Science, 50, 2008, 2993 - 2998. New About Organic

[8] Hmamou, D. Ben; Zarrouk, A.; Salghi, R.; Zarrouk, H.; Ebneso, Eno. E.; Hammouti, B.; Kabanda, M. M.; Benchat, N.; Benali, O. Experimental and Tehortical Studies of the Adsorption and Corrosion Inhibition of 6-phenilpyridazine-3(2H)-thione on Carbon Steel in 2.0 M H3PO4 Solution. International Journal of Electrochemical Science, 2014, 9, 120 - 138.

[9] Bouklah, M.; Hammouti, B.; Lagrenée, M.; Bentiss, F. Thermodynamic properties of 2,5-bis(4methoxyphenyl)-1,3,4-oxadiazole as a corrosion inhibitor for mild steel in normal sulfuric acid medium. Corrosion Science, 3006, 48, 2831 - 2842.

[10] Krim, O., Bouachrine, M., Hammouti, B., Elidrissia, A., Hamidib, M., 2008. Port. Electrochim. Acta 26, 283-289.

[11] Quraishi, M.A., Shukla, S.K., 2009. Mater. Chem. Phys. 113, 685- 689.

[12] Thiraviyam, P., and K. Kannan. "A study of synthesized Mannich base inhibition on mild steel corrosion in acid medium." Journal of the Iranian Chemical Society9.6 (2012): 911-921.

[13] Shreir, Lionel Louis, ed. Corrosion: corrosion control. Vol. 2. Newnes, 2013.

[14] Revie, R. Winston. Corrosion and corrosion control.John Wiley \& Sons, 2008.

[15] I. A. Zaafarany and Hamza A. Ghulman."Ethoxylated fatty amines as corrosion inhibitors for carbon steel in hydrochloric acid solutions"Int. J. Corros. Scale Inhib., 2013, 2, no. 2, 82-91.

[16] Hackerman, Norman, and A. C. Makrides. "Action of polar organic inhibitors in acid dissolution of metals." Industrial \& Engineering Chemistry 46.3 (1954): 523-527. 
[17] Özcan, M., I. Dehri, and M. Erbil. "Organic sulphur-containing compounds as corrosion inhibitors for mild steel in acidic media: correlation between inhibition efficiency and chemical structure." Applied Surface Science 236.1 (2004): 155-164.

[18] Bishof, C.; Carter, D.; Vogt, F. Orthophosphate corrosion inhibitors and their use. US patent 3,837,803A, Sept. 1974.

[19] Şahin, M.; Bilgiç, S.; Yılmaz, H. The inhibition effects of some cyclic nitrogen compounds on the corrosion of the steel in NaCl mediums. Applied Surface Science. 195, 2002, 1-7.

[20] Larabi, L.; Harek, Y.; Traisnel,M.; Mansri, A. Synergistic Influence of Poly(4-Vinylpyridine) and Potassium Iodide on Inhibition of Corrosion of Mild Steel in 1M HCl. Journal of Applied Electrochemistry, 2004, 34, 8, $833-830$.

[21] http://corrosion-doctors.org/Electrochem/PotPol.htm, accessed on October 15, 2016.

[22] R. Epshiba, A. Peter Pascal and S. Rajendran, "Inhibitive effect of aqueous extract of aloe vera and sodium molybdate - zn+2 system on carbon steel", International Journal of Innovative Research in Science, Engineering and Technology, vol.4, no. 1, pp. 39 - 46, 2015.

[23] A. Etheram, "Comparative study on the corrosion inhibition of mild steel by aqueous extract of fenugreek seeds and leaves in acidic solutions", Journal of Engineering and Applied Sciences , vol.3, no. 1, pp. $23-30,2008$.

[24] Green Corrosion Inhibitors: Theory and Practice, First Edition. V. S. Sastri. 2011 John Wiley \& Sons, Inc. Published 2011 by John Wiley \& Sons, Inc.

\section{AUTHOR's BIOGRAPHY}

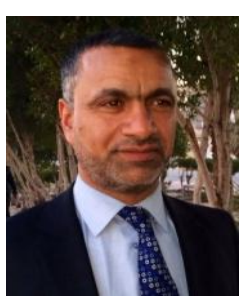

Dr. Adnan A. Ateeq, is presently working as Assistant Professor and dean of Basra Engineering Technical College, Southern Technical University, Iraq. He is having 20 years teaching experience and 9 years research experience. Presently 5 research students are doing their Msc. research work. He is member of STU Academic Council. He has total 16 publications in National and International journals and conferences. His field of interest is design of chemical reactors and transport phenomena. 